\title{
PERTANGGUNG JAWABAN PIDANA BAGI NOTARIS YANG MELAKUKAN \\ TINDAK PIDANA PEMALSUAN SURAT DALAM PEMBUATAN \\ AKTA OTENTIK
}

Oleh :

MOCHAMAD SYAFRIZAL B. S.H. M.Kn ${ }^{\infty}$

\begin{abstract}
ABSTRAK
Dikeluarkannya Undang-Undang Nomor 30 Tahun 2004 tentang Jabatan Notaris diatur bahwa ketika Notaris dalam menjalankan tugas jabatannya terbukti melakukan pelanggaran, maka Notaris dapat dikenai atau dijatuhi sanksi berupa sanksi perdata dan administrasi. Tetapi UUJN tidak mengatur sanksi pidana terhadap Notaris. Dalam praktik ditemukan kenyataan bahwa suatu pelanggaran yang dilakukan Notaris sebenarnya dapat dijatuhi sanksi administrasi atau perdata, tapi kemudian ditarik atau dikualifikasikan sebagai suatu tindak pidana. Notaris yang melakukan tindak pidana pemalsuan surat dalam pembuatan Akta Otentik dapat dipertanggungjawabkan secara pidana apabila memenuhi unsur-unsur kesalahan, yaitu mampu bertanggung jawab, ada hubungan batin berupa kesengajaan dan tidak ada alasan yang menghapuskan kesalahan. Sehingga Notaris yang dengan penuh kesadaran sengaja atau terlibat dalam pembuatan akta otentik palsu dapat dipertanggungjawabkan dalam hukum pidana. Sedangkan apabila unsur-unsur kesalahan tersebut tidak terpenuhi maka Notaris tersebut tidak dapat dipidana.
\end{abstract}

Kata kunci : pertanggungjawaban pidana, notaris, akta otentik

\section{PENDAHULUAN}

Pada tahun 2004 diundangkan Undang-Undang Nomor 30 Tahun 2004 tentang Jabatan Notaris atau disebut UUJN pada tanggal 6 Oktober 2004. Notaris adalah pejabat umum yang berwenang untuk membuat akta otentik sejauh pembuatan akta otentik tertentu tidak dikhususkan bagi pejabat umum lainnya. Pembuatan akta otentik tertentu ada yang diharuskan oleh peraturan perundang-undangan dalam rangka menciptakan kepastian, ketertiban, dan perlindungan hukum. Selain akta otentik yang dibuat oleh atau di hadapan Notaris, bukan saja karena diharuskan oleh peraturan

\footnotetext{
${ }^{\infty}$ Dosen Fakultas Hukum Universitas Islam Balitar.
} 
perundang-undangan, tetapi juga karena dikehendaki oleh pihak yang berkepentingan untuk memastikan hak dan kewajiban para pihak yang berkepentingan demi kepastian, ketertiban, dan perlindungan hukum bagi pihak yang berkepentingan sekaligus bagi masyarakat secara keseluruhan. ${ }^{1}$

Salah satu pembaharuan di dalam UUJN yaitu mengenai sanksi terhadap Notaris dalam menjalankan tugas jabatannya jika melanggar pasal-pasal tertentu dalam UUJN dan Pengawasan terhadap Notaris yang dilakukan oleh suatu Majelis Pengawas yang terdiri dari unsur Notaris, Pemerintah, dan Akademisi.

Sanksi-sanksi merupakan bagian penutup yang penting di dalam hukum. ${ }^{2}$ Adanya sanksi-sanksi tersebut dimaksudkan agar Notaris dapat bertindak benar sesuai dengan UUJN sehingga produk Notaris berupa akta Otentik yang dapat memberikan perlindungan dan kepastian hukum kepada para pihak yang membutuhkannya.

Dalam praktik ditemukan kenyataan bahwa suatu pelanggaran yang dilakukan Notaris sebenarnya dapat dijatuhi sanksi administrasi atau perdata atau kode etik jabatan Notaris, tapi kemudian ditarik atau dikualifikasikan sebagai suatu tindak pidana yang dilakukan oleh Notaris. Jika ada akta Notaris dipermasalahkan oleh para pihak atau pihak lainnya, maka sering pula Notaris ditarik sebagai pihak yang turut serta melakukan atau membantu melakukan suatu tindak pidana, yaitu membuat atau memberikan keterangan palsu ke dalam akta Notaris. Hal ini menimbulkan kerancuan, apakah mungkin Notaris secara sengaja (dolus) bersama-sama para penghadap/pihak untuk membuat akta yang diniatkan sejak awal untuk melakukan suatu tindak pidana? ${ }^{3}$

Fenomena banyaknya Notaris yang tersangkut masalah hukum akhir-akhir ini, seperti adanya pemanggilan oleh pihak kepolisian menyangkut akta yang dibuat menunjukkan masih belum jelasnya kedudukan pertanggungjawaban jabatan Notaris. Hal tersebut akan semakin menimbulkan kekhawatiran Notaris dalam menjalankan tugasnya karena sewaktu-waktu ia dapat digugat oleh para pihak, bahkan ada kemungkinan mendapatkan tuntutan secara pidana. ${ }^{4}$ Sebenarnya kekhawatiran tersebut tidak perlu terjadi asalkan Notaris telah menjalankan tugas dan kewenangannya sesuai dengan ketentuan hukum yang berlaku.

\footnotetext{
${ }^{1}$ Supriadi, Etika \& Tanggung Jawab Profesi Hukum Di Indonesia, Sinar Grafika, Jakarta, 2008, hlm. 29.

${ }^{2}$ Philipus M. Hadjon, dkk, Pengantar Hukum Administrasi Indonesia, Gadjah Mada University Press, Yogyakarta, 2002, hlm. 245.

${ }^{3}$ Habib Adjie, Hukum Notaris Indonesia, Refika Aditama, Bandung, 2008, hlm. 24.

4 Abdul Ghofur Anshori, Lembaga Kenotariatan Indonesia Perspektif Hukum dan Etika, UII Press, Yogyakarta, 2009, hlm. 183.
} 


\section{PERMASALAHAN}

1. Dalam hal bagaimana pembuatan akta otentik oleh Notaris sebagai Pejabat Umum dikategorikan sebagai tindak pidana pemalsuan surat?

2. Bagaimana pertanggungjawaban pidana bagi Notaris sebagai Pejabat Umum yang melakukan tindak pidana pemalsuan surat dalam pembuatan akta otentik?

\section{HASIL DAN PEMBAHASAN}

\subsection{Pembuatan Akta Otentik Oleh Atau Di Hadapan Notaris Sebagai Pejabat} Umum Yang Dikategorikan Sebagai Tindak Pidana Pemalsuan Surat

Mengenai ketentuan pidana tidak diatur di dalam UUJN. UUJN hanya mengatur sanksi atas pelanggaran yang dilakukan oleh Notaris terhadap UUJN, sanksi tersebut dapat berupa sanksi perdata (Pasal 84 UUJN) maupun sanksi administratif (Pasal 85 UUJN). Sedangkan pertanggungjawaban pidana bagi Notaris diatur dalam KUHP apabila Notaris melakukan tindak pidana pemalsuan surat.

Tindak pidana adalah perbuatan yang dilarang oleh suatu aturan hukum, larangan tersebut disertai ancaman atau sanksi yang berupa pidana tertentu bagi yang melanggar larangan tersebut. Unsur-unsur dalam tindak pidana meliputi:

a. Perbuatan (manusia)

perbuatan adalah tindakan dan kejadian yang ditimbulkan oleh perbuatan tersebut. Menurut Moeljatno, di dalam hukum pidana perbuatan ada yang bersifat positif maupun negatif. Positif berarti terdakwa berbuat sesuatu sedangkan negatif berarti seseorang tidak berbuat sesuatu yang diwajibkan atasnya.

b. Memenuhi rumusan peraturan perundang-undangan

Agar suatu perbuatan dapat disebut sebagai tindak pidana harus memenuhi rumusan undang-undang artinya berlaku Asas Legalitas. Asas legalitas menyatakan bahwa "Nullum delictum nulla poena sine praevia lege" yang memiliki makna bahwa tidak ada perbuatan yang dilarang dan diancam dengan pidana jika hal tersebut tidak ada atau belum dinyatakan dalam suatu aturan undang-undang. Arti penting adanya asas legalitas adalah untuk menjamin adanya kepastian hukum dan demi keadilan. Memenuhi peraturan perundang-undangan sebagai syarat dari tindak pidana adalah merupakan syarat formil. 
c. Bersifat melawan hukum

Adanya sifat melawan hukum dalam tindak pidana merupakan syarat mutlak dan juga merupakan syarat materiil. Setidaknya ada dua pendapat mengenai arti dari unsur sifat melawan hukum yang merupakan terjemahan dari bahasa Belanda wederrechtelijk. Pendapat tersebut adalah ajaran mengenai wederrechtlijk dalam arti formil dan dalam arti materiil. ${ }^{5}$

Menurut ajaran wederrechtlijk dalam arti formil suatu perbuatan dapat dipandang sebagai bersifat melawan hukum apabila perbuatan tersebut memenuhi semua unsur yang terdapat di dalam rumusan suatu delik menurut undang-undang. Sedangkan ajaran wederrechtlijk dalam arti materiil menilai suatu perbuatan digolongkan sebagai bersifat melawan hukum atau tidak, perbuatan tersebut tidak hanya ditinjau dari segi yuridis formal semata namun juga harus ditinjau dan diukur menggunakan asasasas hukum umum dari hukum yang tidak tertulis.

Indonesia sendiri menganut ajaran melawan hukum dalam arti materiil namun dalam fungsinya yang negatif, artinya meskipun apa yang dituduhkan secara formil memenuhi rumusan undang-undang hukum pidana namun secara materiil hakim harus memperhatikan juga adanya kemungkinan keadaan dari terdakwa atas dasar mana mereka tidak dapat dihukum, sehingga terdakwa bebas dari segala tuntutan hukum.

Rumusan Kitab Undang-Undang Hukum Pidana (KUHP) mengenai tindak pidana yang erat kaitannya dengan jabatan Notaris dalam pembuatan akta otentik adalah tindak pidana pemalsuan surat pada umumnya (Pasal 263 ayat 1), pemalsuan surat yang diperberat (Pasal 264 ayat 1) dan menyuruh memasukkan keterangan palsu ke dalam akta otentik (Pasal 266 ayat 1).

Pembuatan akta otentik oleh Notaris yang dikategorikan sebagai tindak pidana pemalsuan surat berarti perbuatan yang memenuhi unsur-unsur dalam rumusan Pasal 263 ayat 1 , Pasal 264 ayat 1 dan Pasal 266 ayat 1 KUHP.

Pasal 263 ayat 1 KUHP berbunyi:

Barang siapa membuat surat palsu atau memalsukan surat yang dapat menimbulkan sesuatu hak, perikatan atau pembebasan hutang, atau yang diperuntukkan sebagai bukti dari pada sesuatu hal dengan maksud untuk memakai atau menyuruh orang lain memakai surat tersebut seolah-olah isinya benar dan tidak dipalsu, dipidana 
${ }^{5}$ Moeljatno, op.cit., hlm 130. 
jika pemakaian tersebut dapat menimbulkan kerugian, karena pemalsuan surat, dengan pidana penjara paling lama 6 tahun.

Rumusan Pasal 263 ayat 1 KUHP terdiri dari unsur-unsur sebagai berikut:

a. Unsur-unsur obyektif:

1) Perbuatan: a) membuat palsu;

b) memalsu;

2) Obyeknya: yakni surat:

a) yang dapat menimbulkan suatu hak;

b) yang menimbulkan suatu perikatan;

c) yang menimbulkan suatu pembebasan hutang;

d) yang diperuntukkan sebagai bukti daripada sesuatu hal;

3) dapat menimbulkan akibat kerugian dari pemakaian surat tersebut.

b. Unsur Subyektif: dengan maksud untuk memakai atau menyuruh orang lain memakai seolah-olah isinya benar dan tidak dipalsu.

Unsur obyektif dari tindak pidana pemalsuan surat yang dimaksudkan di dalam ketentuan pidana yang diatur dalam Pasal 263 ayat 1 KUHP ialah perbuatan membuat palsu atau memalsukan.

Menurut Prof. Satochid Kartanegara, perbedaan antara membuat palsu dengan memalsukan ialah bahwa:

1. pada perbuatan membuat palsu pada mulanya tidak terdapat sepucuk surat apapun, tetapi kemudian telah dibuat sepucuk surat yang isinya bertentangan dengan kebenaran;

2. pada perbuatan memalsukan sejak semula memang sudah terdapat sepucuk surat, yang isinya kemudian telah diubah dengan cara yang sedemikian rupa, hingga menjadi bertentangan dengan kebenaran. ${ }^{6}$

Membuat surat palsu (membuat palsu valselijk opmaaken sebuah surat) adalah membuat sebuah surat yang seluruh atau sebagian isinya palsu. Palsu artinya tidak benar atau bertentangan dengan yang sebenarnya.

Membuat surat palsu ini dapat berupa:

1. Membuat sebuah surat yang sebagian atau seluruh isi surat tidak sesuai atau bertentangan dengan kebenaran. Membuat surat palsu yang demikian disebut dengan pemalsuan intelektual (intelectuele valschheid);

${ }^{6}$ Lamintang dan Samosir, Hukum Pidana Indonesia, Cetakan Kedua, Sinar Baru, Bandung, 1985, hlm. 161. 
2. Membuat sebuah surat yang seolah-olah surat itu berasal dari orang lain selain si pembuat surat. Membuat surat palsu yang demikian ini disebut dengan pemalsuan materiil (materiele valschheid). Palsunya surat atau tidak benarnya surat terletak pada asalnya atau si pembuat surat.

Disamping isinya dan asalnya surat yang tidak benar dari membuat surat palsu, menurut Simons, dapat juga tanda tangannya yang tidak benar.

Tentang hal tersebut Simons berkata bahwa:

Het valselijk opmaken kan betrekking hebben zowel op de ondertekening als op den inhoud van het geschrift en allereerst daarin bestaan, dat het geschrift hetzij geheel, hetzij allen wat betreft ondertekening of inhoud valselijk wordt voorgesteld als ofkomstig van dengene, wiens naam onder het geschrift vermeld staat. $^{7}$ Artinya:

Perbuatan membuat secara palsu dapat berkenaan dengan perbuatan baik mengenai tanda tangannya maupun mengenai isinya, hingga sepucuk surat itu baik seluruhnya maupun hanya sebagian yang berkenaan dengan tanda tangannya saja atau yang berkenaan dengan isinya, secara palsu telah dibuat seolah-olah berasal dari orang yang namanya tertulis di bawah surat tersebut.

Hal ini dapat terjadi dalam hal misalnya:

1. Membuat dengan meniru tanda tangan seseorang yang tidak ada orangnya, seperti orang yang telah meninggal dunia secara fiktif (dikarang-karang);

2. Membuat dengan meniru tanda tangan orang lain baik dengan persetujuannya ataupun tidak. ${ }^{8}$

Dalam Akta Notaris ada yang disebut dengan Akta Relass dan Akta Partij. Akta Relass adalah akta yang dibuat oleh Notaris yang menguraikan secara otentik sesuatu tindakan yang dilakukan atau suatu keadaan yang dilihat atau disaksikan oleh pembuat akta itu, yakni Notaris sendiri, di dalam menjalankan jabatannya sebagai Notaris. ${ }^{9}$ Jadi Akta Relass adalah keterangan Pejabat berdasarkan apa yang dilihat atau disaksikan sendiri oleh Notaris. Sehingga jika ada kepalsuan atau bertentangan dengan sebenarnya dalam Akta Relass maka dapat dikatakan Notaris membuat surat palsu.

Sedangkan Akta Partij adalah akta yang dibuat di hadapan Notaris atas permintaan para pihak, Notaris berkewajiban untuk mendengarkan pernyataan atau keterangan para pihak yang dinyatakan atau diterangkan sendiri oleh para pihak di hadapan Notaris, pernyataan atau keterangan para pihak tersebut oleh Notaris

${ }^{7}$ P.A.F. Lamintang \& Theo Lamintang, Delik-Delik Khusus Kejahatan Membahayakan Kepercayaan Umum Terhadap Surat, Alat Pembayaran, Alat Bukti, dan Peradilan, Sinar Grafika, Jakarta, 2009, hlm. 11 .

${ }^{8}$ Adami Chazawi, Kejahatan Mengenai Pemalsuan, Raja Grafindo Persada, Jakarta, 2005, hlm. 100.

${ }^{9}$ G.H.S. Lumban Tobing, op.cit., hlm. 51. 
dituangkan ke dalam akta Notaris. Sehingga yang pasti secara otentik pada Akta Partij ialah: ${ }^{10}$

1. tanggal dari akta itu;

2. tanda tangan yang ada dalam akta itu;

3. identitas dari orang-orang yang hadir (comparanten);

4. bahwa apa yang tercantum dalam akta itu sesuai dengan apa yang diterangkan oleh para penghadap kepada Notaris untuk dicantumkan dalam akta itu, sedangkan kebenaran dari keterangan-keterangan itu sendiri hanya pasti antara pihak-pihak yang bersangkutan sendiri.

Oleh karena itu, membuat palsu dalam Akta Partij berarti apabila empat hal yang harus pasti secara otentik tersebut di atas tidak benar atau bertentangan dengan yang sebenarnya.

Perbuatan memalsu (vervalsen) surat adalah berupa perbuatan mengubah dengan cara bagaimanapun oleh orang yang tidak berhak atas sebuah surat yang berakibat sebagian atau seluruh isinya menjadi lain/berbeda dengan isi surat semula. Tidak penting apakah dengan perubahan itu lalu isinya menjadi benar ataukah tidak atau bertentangan dengan kebenaran ataukah tidak, bila perbuatan mengubah itu dilakukan oleh orang yang tidak berhak, memalsu surat telah terjadi. Orang yang tidak berhak itu adalah orang selain si pembuat surat. ${ }^{11}$

Sama halnya dengan membuat surat palsu, memalsu surat dapat terjadi selain terhadap sebagian atau seluruh isi surat, dapat juga pada tanda tangan si pembuat surat.

Dalam Undang-undang Jabatan Notaris dijelaskan bahwa pada dasarnya isi akta Notaris tidak boleh diubah atau ditambah, baik berupa penulisan tindih, penyisipan, pencoretan, atau penghapusan dan menggantinya dengan yang lain. Tetapi ada pengecualian, dalam akta Notaris dapat dilakukan perubahan berupa penambahan, penggantian, atau pencoretan dalam akta yang hanya sah apabila perubahan tersebut diparaf atau diberi tanda pengesahan lain oleh penghadap, saksi, dan Notaris. ${ }^{12}$

Dalam Akta Notaris, Notaris juga berwenang membetulkan kesalahan tulis dan/atau kesalahan ketik yang terdapat pada Minuta Akta yang telah ditandatangani dengan membuat berita acara dan memberikan catatan tentang hal tersebut pada Minuta

\footnotetext{
${ }^{10}$ Ibid, hlm. 53.

${ }^{11}$ Adami Chazawi, op.cit., hlm. 100.
} 
Akta asli dengan menyebutkan tanggal dan nomor akta berita acara pembetulan. Salinan akta berita acara tersebut wajib disampaikan kepada para pihak. ${ }^{13}$

Sehingga Notaris yang melakukan perubahan terhadap Akta Notaris dengan cara yang ditentukan dalam UUJN bukan termasuk dalam perbuatan memalsukan surat. Sebaliknya jika perubahan tersebut tidak sesuai dengan cara yang ditentukan dalam UUJN, maka termasuk dalam perbuatan memalsukan surat.

Unsur obyektif selanjutnya dari ketentuan Pasal 263 ayat 1 KUHP adalah obyek pemalsuan surat dibatasi 4 macam surat, yaitu:

1. surat yang menimbulkan suatu hak;

2. surat yang menimbulkan suatu perikatan;

3. surat yang menimbulkan pembebasan hutang;

4. surat yang diperuntukkan bukti mengenai suatu hal.

Pada umumnya sebuah surat tidak melahirkan secara langsung adanya suatu hak, melainkan hak itu timbul dari adanya perikatan hukum (perjanjian) yang tertuang dalam surat itu, tetapi ada surat-surat tertentu yang disebut surat formil yang langsung melahirkan suatu hak tertentu, misalnya cek, bilyet giro, wesel, surat izin mengemudi, ijazah dan lain sebagainya.

Surat yang berisi suatu perikatan pada dasarnya adalah berupa surat yang karena perjanjian itu melahirkan hak. Misalnya surat jual beli melahirkan hak si penjual untuk menerima uang pembayaran harga benda, dan pembeli mempunyai hak untuk memperoleh atau menerima benda yang dibelinya.

Begitu juga dengan surat yang berisi pembebasan hutang. Lahirnya pembebasan hutang pada dasarnya disebabkan karena dan dalam hubungannya dengan suatu perikatan. Misalnya suatu kuitansi yang berisi penyerahan sejumlah uang tertentu dalam hal dan dalam hubungannya dengan misalnya jual beli, hutang piutang dan lain sebagainya.

Mengenai unsur "surat yang diperuntukkan sebagai bukti akan adanya sesuatu hal", di dalamnya ada 2 hal yang perlu dibicarakan, yakni:

1. Mengenai diperuntukkan sebagai bukti;

2. Tentang sesuatu hal.

Diperuntukkan sebagai bukti adalah karena sifatnya surat itu memiliki kekuatan pembuktian (bewijskracht). Siapa yang menentukan bahwa adanya kekuatan 
pembuktian atas sesuatu hal dalam sebuah surat itu? Dalam hal ini bukan pembuat yang dapat menentukan demikian, melainkan Undang-Undang atau kekuasaan tata usaha negara.

Dalam Undang-Undang, seperti pasal 1870 KUHPerdata yang menyatakan bahwa akta otentik bagi para pihaknya beserta ahli warisnya atau orang yang mendapatkan hak dari pada mereka merupakan bukti sempurna tentang apa yang dimuat di dalamnya.

Surat-surat yang termasuk dalam akta otentik dan mempunyai kekuatan pembuktian sempurna akan sesuatu hal adalah surat-surat yang dibuat oleh atau dihadapan pejabat yang berwenang dan dalam bentuk yang ditentukan undang-undang. Surat yang memiliki kekuatan pembuktian sempurna seperti ini diantaranya adalah akta otentik yang dibuat oleh atau dihadapan Notaris.

Ketentuan pidana yang diatur dalam Pasal 264 ayat 1 KUHP merupakan lex specialis dari ketentuan pidana yang diatur dalam Pasal 263 ayat 1 KUHP dan tindak pidana pemalsuan surat yang dimaksudkan dalam Pasal 264 ayat 1 KUHP merupakan tindak pidana pemalsuan surat dengan kualifikasi. ${ }^{14}$

Kata-kata "pemalsuan surat" di dalam rumusan ketentuan pidana Pasal 264 ayat 1 KUHP mempunyai arti yang sama dengan kata-kata "pemalsuan surat" di dalam rumusan ketentuan pidana dalam Pasal 263 ayat 1 KUHP. ${ }^{15}$ Jadi pemalsuan surat dalam rumusan Pasal 264 ayat 1 KUHP harus memenuhi unsur-unsur Pasal 263 ayat 1 KUHP.

Selanjutnya ketentuan pidana dalam KUHP yang berhubungan dengan pembuatan akta otentik oleh atau dihadapan Notaris adalah Pasal 266 ayat 1 KUHP yang merumuskan sebagai berikut:

Barangsiapa menyuruh memasukkan keterangan palsu ke dalam suatu akta otentik mengenai sesuatu hal yang kebenarannya harus dinyatakan oleh akta itu, dengan maksud untuk memakai atau menyuruh orang lain memakai akta itu seolah-olah keterangannya sesuai dengan kebenaran, dipidana, jika pemakaian itu dapat menimbulkan kerugian, dengan pidana penjara paling lama 7 tahun.

Unsur-unsur Pasal 266 ayat 1 KUHP tersebut adalah:

1. Unsur-unsur obyektif:

a. Perbuatan: menyuruh memasukkan

14 P.A.F. Lamintang \& Theo Lamintang, Delik-Delik Khusus Kejahatan Membahayakan Kepercayaan Umum Terhadap Surat, Alat Pembayaran, Alat Bukti, dan Peradilan, Sinar Grafika, Jakarta, 2009, hlm. 46.

${ }^{15}$ Ibid. 

b. Obyeknya: keterangan palsu;
c. ke dalam akta otentik;
d. mengenai sesuatu hal yang kebenarannya harus dinyatakan dengan akta itu;
e. jika pemakaiannya dapat menimbulkan kerugian;

2. Unsur Subyektif: dengan maksud untuk memakai atau menyuruh memakai seolaholah keterangan itu sesuai dengan kebenaran.

Dalam rumusan tersebut di atas, tidak dicantumkan siapa orang yang disuruh untuk memasukkan keterangan palsu tersebut, tetapi dapat diketahui dari unsur/kalimat "ke dalam akta otentik" dalam rumusan Pasal 266 ayat 1 tersebut. Bahwa orang tersebut adalah si pembuat akta otentik, dalam pembahasan ini adalah Notaris.

Notaris sebagai Pejabat Umum dalam pembuatan suatu akta otentik adalah memenuhi permintaan para pihak. Para pihak yang meminta inilah yang dimaksud orang yang menyuruh memasukkan keterangan palsu.

Perbuatan menyuruh memasukkan mengandung unsur-unsur:

1. Inisiatif atau kehendak untuk membuat akta, akta mana memuat tentang apa (obyek yakni: mengenai sesuatu hal) yang disuruh masukkan ke dalamnya adalah berasal dari orang yang menyuruh memasukkan, bukan dari pejabat pembuat akta otentik;

2. Dalam hubungannya dengan asalnya inisiatif dari orang yang meminta dibuatkannya akta otentik, maka dalam perkataan/unsur menyuruh memasukkan berarti orang itu dalam kenyataannya ia memberikan keterangan-keterangan tentang sesuatu hal, hal mana adalah bertentangan dengan kebenaran atau palsu.

3. Pejabat pembuat akta otentik tidak mengetahui bahwa keterangan yang disampaikan oleh orang yang menyuruh memasukkan keterangan kepadanya itu adalah keterangan yang tidak benar.

4. Oleh karena pejabat pembuat akta otentik tidak mengetahui perihal tidak benarnya keterangan tentang sesuatu hal itu, maka ia tidak dapat dipertanggungjawabkan, terhadap perbuatannya yang melahirkan akta otentik yang isinya palsu itu, dan karenanya ia tidak dapat dipidana. ${ }^{16}$

Untuk selesainya perbuatan menyuruh memasukkan dalam arti selesainya kejahatan itu secara sempurna, tidak cukup dengan selesainya perbuatan memberikan keterangan tentang sesuatu hal/kejadian, melainkan harus sudah ternyata tentang hal/kejadian itu telah nyata-nyata dimuatnya dalam akta otentik yang dimaksudkan.

\footnotetext{
${ }^{16}$ Adami Chazawi, Kejahatan Mengenai Pemalsuan, Raja Grafindo Persada, Jakarta, 2005, hlm. 113.
} 
Apabila setelah memberikan keterangan perihal sesuatu kejadian yang diminta masukkan ke dalam akta otentik pada pejabat pembuatnya, sedang akta itu sendiri belum dibuatnya atau keterangan tentang perihal kejadian itu belum dimasukkan kedalam akta, kejahatan itu belum terjadi secara sempurna, melainkan baru terjadi percobaan tindak pidana menyuruh memberikan keterangan palsu ke dalam akta otentik saja.

Obyek kejahatan ini adalah keterangan palsu, artinya suatu keterangan yang bertentangan dengan kebenaran, keterangan mana mengenai sesuatu hal/kejadian. Tidak semua hal/kejadian berlaku disini, melainkan kejadian yang harus dibuktikan oleh akta otentik itu.

Unsur sesuatu hal dari Pasal 266 ayat 1 KUHP ini sama pengertiannya dengan sesuatu hal dari pasal 263 ayat 1 KUHP. Di sini ada dua paham yang berbeda, yaitu:

1. sesuatu hal adalah isi pokok dari akta otentik tersebut, misalnya akta jual beli isi pokoknya adalah jual beli.

2. sesuatu hal di sini, di samping isi pokoknya juga hal lain yang harus dibuktikan oleh akta otentik tersebut. Misalnya akta jual beli juga membuktikan tentang besarnya harga jual beli.

Unsur subyektif dalam ketentuan Pasal 266 ayat 1 KUHP adalah "dengan maksud untuk memakai akta yang memuat kejadian palsu yang demikian itu seolah- olah keterangan dalam akta itu sesuai dengan kebenaran”. Mengenai unsur subyektif ini pada dasarnya sama dengan unsur subyektif dalam Pasal 263 ayat 1 KUHP.

Demikian juga mengenai unsur "jika pemakaian itu menimbulkan kerugian”, sama dengan Pasal 263 ayat 1 KUHP.

Di dalam ketentuan Pasal 266 ayat 1 KUHP ini, orang yang menyuruh memasukkan keterangan palsu ke dalam Akta Notaris adalah para pihak yang menghadap Notaris. Notaris tidak dapat dikenakan Pasal ini karena Notaris adalah pembuat Akta Notaris tersebut, bukan sebagai orang yang menyuruh. Notaris dapat dikenakan Pasal ini, jika Notaris mengetahui bahwa keterangan itu palsu dan Notaris turut serta memasukkan keterangan palsu tersebut ke dalam akta otentik.

Hal ini sesuai dengan ketentuan Pasal 55 KUHP yang berbunyi sebagai berikut: Dipidana sebagai pembuatan (dader) suatu perbuatan pidana:

Ke-1. Mereka yang melakukan, yang menyuruh lakukan dan yang turut serta melakukan perbuatan; 
Ke-2. Mereka yang dengan memberi atau menjanjikan sesuatu, dengan menyalahgunakan kekuasaan atau martabat, dengan kekerasan, ancaman atau penyesatan atau memberikan sarana atau keterangan, sengaja menganjurkan orang lain supaya melakukan perbuatan.

\subsection{Pertanggungjawaban Pidana Bagi Notaris Sebagai Pejabat Umum Yang}

\section{Melakukan Tindak Pidana Pemalsuan Surat Dalam Pembuatan Akta Otentik}

Notaris sebagai pejabat umum (openbaar ambtenaar) yang berwenang membuat akta otentik dapat dibebani tanggung jawab atas pelaksanaan tugas jabatannya dalam membuat akta tersebut. Salah satu tanggung jawab Notaris adalah tanggung jawab secara pidana atas akta yang dibuatnya. Pertanggungjawaban pidana bagi Notaris diatur dalam KUHP apabila Notaris melakukan tindak pidana pemalsuan surat.

Menurut aliran dualistis, terjadinya tindak pidana belum tentu diikuti dengan pemidanaan. Pemidanaan baru dapat dilakukan apabila orang yang melakukan tindak pidana dapat dipertanggungjawabkan dalam hukum pidana. Sebaliknya apabila orang yang melakukan tindak pidana tidak dapat dipertanggungjawabkan dalam hukum pidana, walaupun ia telah melakukan perbuatan sebagaimana yang dirumuskan dalam undang-undang sebagai tindak pidana ia tidak akan dijatuhi pidana. Ketentuan demikian didasarkan pada asas "tiada pidana tanpa kesalahan". ("Geen Straf Zonder Schuld" atau "actus non facit reummisi mens sit rea" ). ${ }^{17}$

Kesalahan dalam arti yang seluas-luasnya menurut Sudarto terdiri dari beberapa unsur yaitu:

a. Adanya kemampuan pertanggungjawaban pada si pembuat, artinya keadaan jiwa si pembuat harus normal.

b. Adanya hubungan batin antara si pembuat dengan perbuatannya, yang berupa kesengajaan (dolus) atau kealpaan (culpa); ini disebut bentuk-bentuk kesalahan.

c. Tidak ada alasan yang menghapuskan kesalahan atau tidak ada alasan pemaaf. ${ }^{18}$

Kemampuan bertanggung jawab menurut Simons adalah suatu keadaan psikis, yang membenarkan penerapan sesuatu upaya pemidanaan, baik dilihat dari sudut umum orangnya. Seseorang dikatakan mampu bertanggung jawab apabila jiwanya sehat sehingga:

${ }^{17}$ Masruchin Ruba'i, op. cit, hlm. 40.

${ }^{18}$ Ibid, hlm. 43. 
a. Ia mampu untuk mengetahui atau menyadari bahwa perbuatannya bertentangan dengan hukum;

b. Ia dapat menentukan kehendaknya sesuai dengan kesadaran tersebut. ${ }^{19}$

Di dalam Undang-Undang Jabatan Notaris ditentukan syarat untuk dapat diangkat menjadi Notaris, yaitu:

a. warga negara Indonesia;

b. bertaqwa kepada Tuhan Yang Maha Esa;

c. berumur paling sedikit 27 (dua puluh tujuh) tahun;

d. sehat jasmani dan rohani;

e. berijazah sarjana hukum dan lulusan jenjang strata dua kenotariatan;

f. telah menjalani magang atau nyata-nyata telah bekerja sebagai karyawan Notaris dalam waktu 12 (dua belas) bulan berturut-turut pada kantor Notaris atas prakarsa sendiri atau atas rekomendasi Organisasi Notaris setelah lulus strata dua kenotariatan; dan

g. tidak berstatus sebagai pegawai negeri, pejabat negara, advokat, atau tidak sedang memangku jabatan lain yang oleh undang-undang dilarang untuk dirangkap dengan jabatan Notaris. $^{20}$

Syarat untuk dapat diangkat menjadi Notaris diantaranya adalah sehat jasmani dan rohani; dan berijazah sarjana hukum dan lulusan jenjang strata dua kenotariatan sehingga Notaris mampu untuk mengetahui atau menyadari bahwa perbuatannya bertentangan dengan hukum. Oleh karena itu, Notaris yang masih memenuhi syarat tersebut berarti mampu bertanggung jawab.

Unsur kesalahan yang kedua adalah adanya hubungan batin antara si pembuat dengan perbuatannya yang berupa kesengajaan (dolus) atau kealpaan (culpa). Di dalam ketentuan pidana yang diatur dalam Pasal 263 ayat 1 dan Pasal 264 ayat 1 KUHP, pembentuk undang-undang ternyata tidak mensyaratkan keharusan adanya unsur kesengajaan pada diri pelaku.

Menurut Prof. van Hamel, jika di dalam suatu rumusan ketentuan pidana disyaratkan bijkomend oogmerk atau suatu maksud lebih lanjut, maka mau tidak mau tindak pidana yang dimaksudkan di dalamnya harus dilakukan dengan sengaja, 
walaupun unsur kesengajaan itu tidak dinyatakan dengan tegas sebagai salah satu unsur dari tindak pidana yang bersangkutan. ${ }^{21}$

Yang dimaksudkan dengan bijkomend oogmerk pada tindak pidana pemalsuan surat yang dimaksudkan di dalam ketentuan pidana yang diatur dalam Pasal 263 ayat 1 dan Pasal 264 ayat 1 KUHP adalah maksud untuk menggunakannya sebagai surat yang asli dan tidak dipalsukan atau untuk membuat orang lain menggunakan surat tersebut.

Untuk ketentuan Pasal 266 ayat 1 jo 55 KUHP, turut serta memasukkan keterangan palsu ke dalam akta otentik oleh Notaris harus dilakukan dengan sengaja.

Dalam ilmu pengetahuan hukum pidana ditentukan syarat yang harus dipenuhi bagi yang turut melakukan, yaitu:

1. Terdapat beberapa orang melakukan tindak pidana, masing-masing ikut berbuat secara langsung.

2. Mereka yang terlibat melakukan tindak pidana harus mempunyai kesadaran bahwa mereka bekerja sama. ${ }^{22}$

Dalam hal tindak pidana menyuruh memasukkan keterangan palsu ke dalam akta otentik yang melibatkan Notaris, berarti Notaris harus mempunyai kesadaran bahwa Notaris bekerja sama dengan pihak yang menyuruh memasukkan keterangan palsu ke dalam akta otentik.

Unsur kesalahan yang terakhir adalah tidak ada alasan yang menghapuskan kesalahan atau tidak ada alasan pemaaf.

Urutan ketiga unsur kesalahan harus sebagaimana yang diuraikan di atas. Ketiganya merupakan satu kesatuan yang tak dapat dipisahkan. Unsur yang pertama merupakan unsur yang memungkinkan adanya unsur yang kedua. Apabila unsur yang pertama (mampu bertanggung jawab) tidak ada maka tidak mungkin ada kesengajaan atau kealpaan. Unsur yang kedua merupakan unsur yang memungkinkan adanya unsur yang ketiga. Tanpa adanya unsur yang kedua (kesengajaan atau kealpaan) tidak mungkin diperlukan adanya unsur ketiga yaitu alasan pembenar dan alasan pemaaf.

Dengan demikian, jika unsur-unsur kesalahan terpenuhi maka Notaris yang melakukan tindak pidana pemalsuan dapat dipertanggungjawabkan secara pidana. Demikian juga sebaliknya, jika unsur-unsur kesalahan tidak terpenuhi maka Notaris 
yang melakukan tindak pidana pemalsuan tidak dapat dipertanggungjawabkan secara pidana.

\section{KESIMPULAN}

1. Notaris adalah Pejabat Umum yang berwenang membuat Akta Otentik. Pembuatan Akta Otentik tersebut harus berdasarkan bentuk dan prosedur yang sudah ditetapkan di dalam Undang-undang Jabatan Notaris. Pembuatan Akta Otentik oleh atau di hadapan Notaris dikategorikan sebagai tindak pidana pemalsuan surat apabila memenuhi unsur-unsur rumusan tindak pidana pemalsuan surat di dalam Kitab Undang-Undang Hukum Pidana (KUHP), yaitu Pasal 263 ayat 1 KUHP, Pasal 264 ayat 1 KUHP dan Pasal 266 ayat 1 jo Pasal 55 KUHP.

2. Notaris yang melakukan tindak pidana pemalsuan surat dalam pembuatan Akta Otentik dapat dipertanggungjawabkan secara pidana apabila memenuhi unsur-unsur kesalahan, yaitu mampu bertanggung jawab, ada hubungan batin berupa kesengajaan dan tidak ada alasan yang menghapuskan kesalahan. Sehingga Notaris yang dengan penuh kesadaran sengaja atau terlibat dalam pembuatan akta otentik palsu dapat dipertanggungjawabkan dalam hukum pidana. Sedangkan apabila unsur-unsur kesalahan tersebut tidak terpenuhi maka Notaris tersebut tidak dapat dipidana.

\section{Saran}

1. Pembuatan Akta Otentik oleh atau di hadapan Notaris harus sesuai dengan bentuk dan prosedur di dalam Undang-Undang Jabatan Notaris agar tercipta kepastian hukum bagi masyarakat yang menggunakan jasa Notaris dan agar Notaris terhindar dari sanksi pidana.

\section{DAFTAR PUSTAKA}

A. Muktie Fadjar, Tipe Negara Hukum, Bayumedia Publishing, Malang, 2005.

Abdul Ghofur Anshori, Lembaga Kenotariatan Indonesia Perspektif Hukum dan Etika, UII Press, Yogyakarta, 2009

Abdulkadir Muhammad, Etika Profesi Hukum, Citra Aditya Bakti, Bandung, 2006.

E. Sumaryono, Etika Profesi Hukum: Norma-Norma Bagi Penegak Hukum, Kanisivs, Yogyakarta, 1995 
Franz Magnis Suseno, Etika Politik Prinsip-Prinsip Moral Dasar KeNegaraan Modern, Gramedia Pustaka Utama, Jakarta, 2001

G.H.S. Lumban Tobing, Peraturan Jabatan Notaris, Erlangga, Jakarta, 1983

Green Mind Community, Teori dan Politik Hukum Tata Negara, Total Media, Yogyakarta, 2009

Habib Adjie, Sanksi Perdata dan Administratif Terhadap Notaris Sebagai Pejabat Publik, Refika Aditama, Bandung, 2008

Habib Adjie, Hukum Notaris Indonesia, Refika Aditama, Bandung, 2008

http://www.hukumonline.com, Ketika Notaris Dipanggil Polisi, Diakses Tanggal 10 April 2009

\section{Peraturan Perundang-undangan}

Undang-Undang RI No. 30 Tahun 2004 tentang Jabatan Notaris

Kitab Undang-Undang Hukum Pidana. 